\title{
Streptococcus pneumoniae stabilizes tumor necrosis factor $\alpha$ mRNA through a pathway dependent on p38 MAPK but independent of Toll-like receptors
}

\author{
Trine H Mogensen*1, Randi S Berg1,2, Lars Østergaard ${ }^{1}$ and Søren R Paludan ${ }^{2}$
}

Address: ${ }^{1}$ Department of Infectious Diseases, Skejby Hospital - Aarhus University Hospital, DK-8200, Aarhus N, Denmark and ${ }^{2}$ Institute of Medical Microbiology and Immunology, University of Aarhus, DK-8000, Aarhus C, Denmark

Email: Trine H Mogensen* - trine.mogensen@dadlnet.dk; Randi S Berg - rsb@studmed.au.dk; Lars Østergaard - oes@sks.aaa.dk; Søren R Paludan - srp@microbiology.au.dk

* Corresponding author

Published: 16 September 2008

BMC Immunology 2008, 9:52 doi:10.1 186/147|-2172-9-52
Received: 15 February 2008

Accepted: 16 September 2008

This article is available from: http://www.biomedcentral.com/147I-2172/9/52

(C) 2008 Mogensen et al; licensee BioMed Central Ltd.

This is an Open Access article distributed under the terms of the Creative Commons Attribution License (http://creativecommons.org/licenses/by/2.0), which permits unrestricted use, distribution, and reproduction in any medium, provided the original work is properly cited.

\begin{abstract}
Background: Streptococcus pneumoniae is a human pathogenic bacteria and a major cause of severe invasive diseases, including pneumonia, bacteremia, and meningitis. Infections with $S$. pneumoniae evoke a strong inflammatory response, which plays a major role in the pathogenesis of pneumococcal disease.

Results: In this study, we have examined how S. pneumoniae affects expression of the inflammatory cytokine tumor necrosis factor (TNF) $\alpha$, and the molecular mechanisms involved. Secretion of TNF- $\alpha$ was strongly induced by S. pneumoniae, which was able to stabilize TNF- $\alpha$ mRNA through a mechanism dependent on the viability of the bacteria as well as the adenylate uridylate-rich elements in the 3'untranslated region of TNF- $\alpha$ mRNA. The ability of S. pneumoniae to stabilize TNF- $\alpha$ mRNA was dependent on the mitogen-activated protein kinase (MAPK) p38 whereas inhibition of Toll-like receptor signaling via MyD88 did not affect $S$. pneumoniae-induced mRNA stabilization. P38 was activated through a pathway involving the upstream kinase transforming growth factor-activated kinase I and MAPK kinase 3.
\end{abstract}

Conclusion: Thus, $S$. pneumoniae stabilizes TNF- $\alpha$ mRNA through a pathway dependent on p38 but independent of Toll-like receptors. Production of TNF- $\alpha$ may contribute significantly to the inflammatory response raised during pneumococcal infection.

\section{Background}

Streptococcus pneumoniae is an important cause of severe invasive infections, including pneumonia, bacteremia, and meningitis $[1,2]$. Nasopharyngeal carriage of $S$. pneumoniae is common among children, but in most cases bacterial invasion into the lungs or bloodstream is prevented by local host defenses in the upper airways [3]. However, in a minority of individuals, pneumocooci gain access to deeper structures of the body and thereby cause invasive disease [3], which are almost uniformly fatal if not treated with antibiotics. Even in the presence of appropriate treatment, invasive pneumococcal disease bears a relatively poor prognosis [4]. Pneumococci are known to elicit a very potent inflammatory response $[1,5]$, a key component of which is the production of cytokines and chemokines, which participate in the elimination of bacteria but 
may also result in undesirable excessive immunological responses, which may be harmful to the host [1].

The cytokine tumor necrosis factor (TNF)- $\alpha$ is produced by macrophages and dendritic cells as a primary response to infections and tissue damage, and is constitutively expressed in several autoimmune diseases [6]. TNF- $\alpha$ plays an important role in activation and recruitment of leukocytes to inflamed tissue [6], and has been demonstrated to be involved in the host-defense against a number of important human pathogens, including $S$. pneumoniae $[7-9]$. However, TNF- $\alpha$ is also associated with excessive inflammation and immunopathology in infections and autoimmune diseases, and specifically, TNF-a has been suggested to be involved in breakage of the blood-brain barrier during development of hematogenous pneumococcal meningitis [10].

Production of TNF- $\alpha$ is regulated both at the level of transcription, mRNA stability, and translation [11-13]. The regulation of mRNA stability and translation is mediated largely through adenylate uridylate (AU)-rich elements (ARE)s present in the 3 -untranslated region (UTR) of mRNA, which are targeted by ARE-binding proteins able to affect mRNA stability and translation $[13,14]$. The importance of AREs in regulation of TNF- $\alpha$ production is evidenced by spontaneous development of chronic inflammatory arthritis and Crohn's-like inflammatory bowel disease in transgenic mice devoid of AREs in mRNA encoding TNF- $\alpha$ [12].

The inflammatory response to infection is triggered by pattern recognition receptors (PRR)s, which recognize evolutionarily conserved pathogen-associated molecular patterns (PAMP)s and activate intracellular signaling, thereby up-regulating expression of genes with inflammatory activities, including TNF- $\alpha$ [15]. The Toll-like receptors (TLR)s constitute an important class of PRRs, and TLR2, 4, and 9 have been shown to recognize pneumococcal PAMPs [3,16-20]. The vast majority of TLR downstream signaling proceeds through the cytoplasmic adaptor protein MyD88, which is central for activation of the transcription factor nuclear factor $(\mathrm{NF}) \kappa \mathrm{B}$, and the mitogen-activated protein kinase (MAPK) pathway, being involved in both transcriptional and post-transcriptional responses [21]. However, several studies suggest that pneumococcal recognition and pathogenesis may be at least partly independent of TLR signaling $[22,23]$. Another class of PRRs involved in recognition of $S$. pneumoniae is the nucleotide-binding oligomerization domain (NOD) proteins, which are intracellular PRRs [24]. The NOD2 protein recognizing muramyl dipeptide has been reported to be important for activation of NF-kB during infection with S. pneumoniae [25].
In this study, we have investigated the role of mRNA stabilization in TNF- $\alpha$ production induced by $S$. pneunomiae, including the signaling mechanisms involved. Here we report that live $S$. pneunomiae strongly stabilizes TNF- $\alpha$ mRNA by a mechanism dependent on the AREs in the 3'UTR of the mRNA. Importantly, increased TNF- $\alpha$ mRNA stability induced by $S$. pneunomiae was not mediated by TLRs but was dependent on the p38 MAPK, which was activated through a pathway involving transforming growth factor-activated kinase (TAK) 1 and MAPK kinase (MKK) 3.

\section{Results}

\section{S. pneumoniae induces TNF- $\alpha$ production and stabilizes TNF- $\alpha$ mRNA through AREs in the 3'-UTR}

Given the important role of the inflammatory response in the pathogenesis of streptococcal diseases [1], we were interested in studying mechanisms involved in expression of inflammatory cytokines during infection with S. pneumoniae. In a first set of experiments, we measured expression of TNF- $\alpha$ in murine macrophages after treatment with $S$. pneumoniae, N. meningitidis or pure ligands for TLR2 (Pam3Csk4), TLR4 (LPS), and TLR9 (ODN1826). As expected, cells responded to addition of bacteria or TLR ligands by secreting high amounts of TNF- $\alpha$ (Fig. 1A). LPS has been reported to stimulate TNF- $\alpha$ expression by both activating gene transcription, stabilizing the TNF- $\alpha$ mRNA, and supporting translation [11-13]. To examine whether $S$. pneumoniae stabilized TNF- $\alpha$ mRNA, we treated cells with actinomycin $\mathrm{D}$, which prevents de novo transcription of mRNA, and stimulated the macrophages with S. pneumoniae, N. meningitidis or LPS. At the indicated time-points post-stimulation, RNA was harvested and TNF- $\alpha$ mRNA levels were determined by real-time PCR. As shown in Fig. 1B, addition of actinomycin D led to a rapid decline in the levels of remaining TNF- $\alpha$ mRNA in cells receiving mock treatment. However, treatment with $S$. pneumoniae profoundly augmented the half-life of TNF- $\alpha$ mRNA (from about 30 min to about 6 hours). LPS and $N$. meningitidis also stabilized the TNF- $\alpha$ messenger but not to the same extent as $S$. pneumoniae. To examine whether the AREs of the TNF- $\alpha$ mRNA were required for the observed effect, we turned to a cell system derived from RAW264.7 cells, consisting of two cell lines stably expressing a reporter gene (chloramphenicol acetyl transferase, CAT), transcribed from a constitutive promoter. In one of the cell lines (RAW TNF- $\alpha$ 3'-UTR AU+) the 3'-UTR of the mRNA encoding the reporter gene is derived from the wild-type TNF- $\alpha$ mRNA, and in the other cell line (RAW TNF- $\alpha$ 3'-UTR AU $\div$ ) the AREs of the TNF- $\alpha$ 3'-UTR are mutated. When the RAW TNF- $\alpha$ 3'-UTR AU+ cell line was incubated in the presence of $S$. pneumoniae, a very strong increase in CAT levels was observed (Fig. 1C), whereas LPS and also N. meningitidis affected accumulation of CAT protein only to a more modest extent. Inter- 

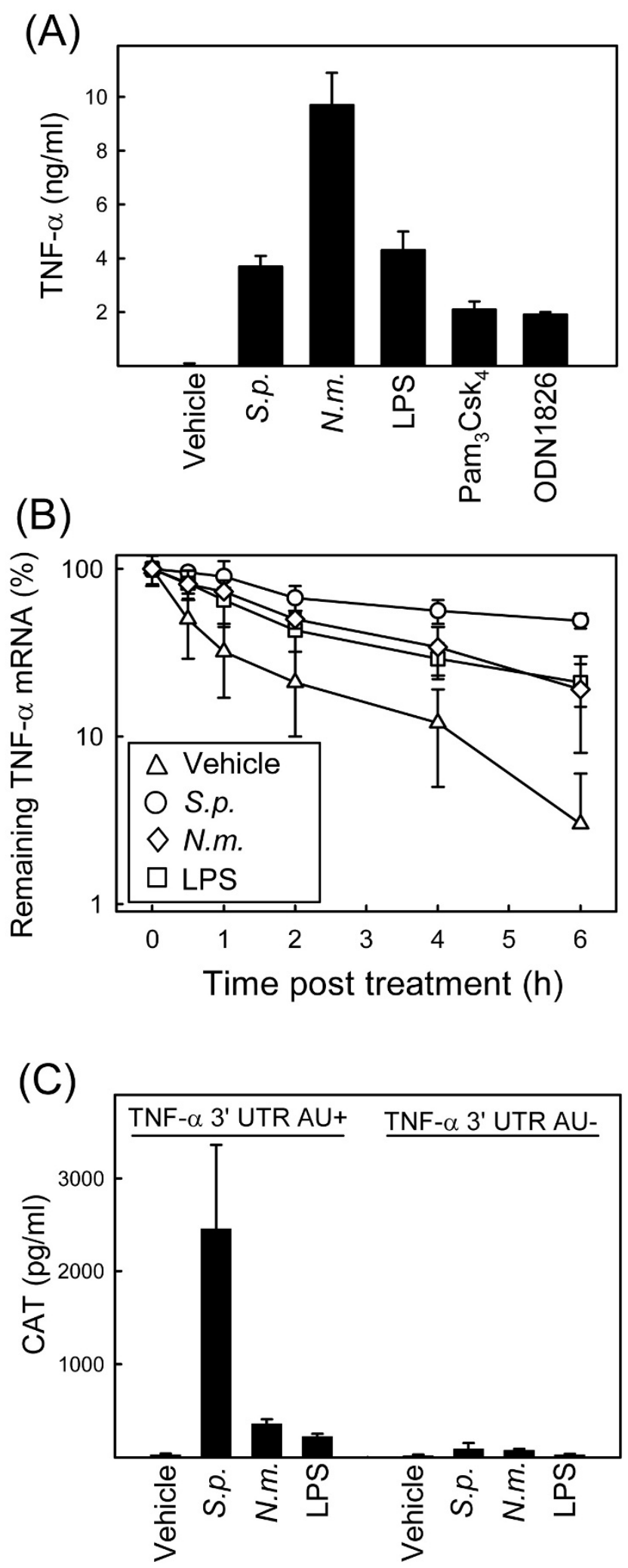

Figure I
Figure I

S. pneumoniae induces TNF- $\alpha$ production and stabilizes TNF- $\alpha$ mRNA through AREs in the 3'-UTR. (A) C57BL/6 macrophages were stimulated with vehicle, S. pneumoniae, $N$. meningitidis $\left(5 \times 10^{7}\right.$ bacteria $\left./ \mathrm{ml}\right)$, LPS $(100 \mathrm{ng} / \mathrm{ml})$, Pam3Csk4 (200 ng/ml), or ODNI826 (I $\mu$ M). Supernatants were harvested $18 \mathrm{~h}$ later, and TNF- $\alpha$ was measured by ELISA. (B) C57BL/6 macrophages were treated with I $\mu \mathrm{M}$ actinomycin D 15 min prior to treatment with vehicle, $S$. pneumoniae, $N$. meningitidis (both $5 \times 10^{7}$ bacteria $/ \mathrm{ml}$ ), or LPS $(100 \mathrm{ng} / \mathrm{ml})$. The cells were lysed at the indicated time points and Total RNA was harvested. TNF- $\alpha$ and $\beta$-actin mRNAs were detected by $\mathrm{qPCR}$, and normalized ratios were calculated. The data is shown as percent remaining TNF- $\alpha$ mRNA compared to untreated control. (C) RAW-TNF-AU+ and RAW-TNF-AU $\div$ cells were seeded and treated with vehicle, S. pneumoniae, $N$. meningitidis (both $5 \times 10^{7}$ bacteria $/ \mathrm{ml}$ ), or LPS (I00 ng/ml). Total cell lysates were harvested $20 \mathrm{~h}$ later and CAT was measured by ELISA. Similar results were obtained in 2-4 independent experiments. The data are shown as means +/- SEM.

estingly, the effect of $S$. pneumoniae on accumulation of CAT was largely abrogated in the RAW TNF- $\alpha$ 3'-UTR AU: cell line. Thus, $S$. pneumoniae stimulates production of TNF- $\alpha$ and stabilizes TNF- $\alpha$ mRNA through a mechanism involving the AREs in the 3'-UTR of the mRNA.

\section{Stabilization of TNF- $\alpha$ mRNA by S. pneumoniae is dependent on the viability of the bacteria}

We next examined the pneumococcal requirement for mediating TNF- $\alpha$ mRNA stability. To this end, we compared the ability of live versus killed bacteria to induce CAT expression in the RAW TNF- $\alpha$ 3'-UTR AU+/AU- cell lines (Fig. 2A and 2B). As also shown in Fig. 1C, S. pneumoniae induced accumulation of CAT, and this was dependent on the 3'-UTR AREs (Fig. 2). Interestingly, $S$. pneumoniae killed either by heat-inactivation, UV light or penicillin displayed reduced ability to induce CAT expression, with the reduction ranging from almost $100 \%$ (heatinactivated bacteria) to about $65 \%$ (penicillin-killed bacterial). Thus, stabilization of TNF- $\alpha$ mRNA by $S$. pneumoniae is dependent on the viability of the bacteria.

\section{S. pneumoniae mediates TNF- $\alpha$ mRNA stability independent of TLRs}

The S. pneumoniae SK1013 strain used in this study has previously been demonstrated to be recognized by TLR2 and $9[16]$, with the former recognizing bacterial peptidoglycan and lipoteichoic acid and the latter recognizing bacterial DNA [16-18,26]. We have previously demonstrated that TLR9 recognizes live but not heat-killed $S$. pneumoniae [16] wherefore the data shown in Fig. 2 prompted us to examine the role of TLR9 in stabilization 

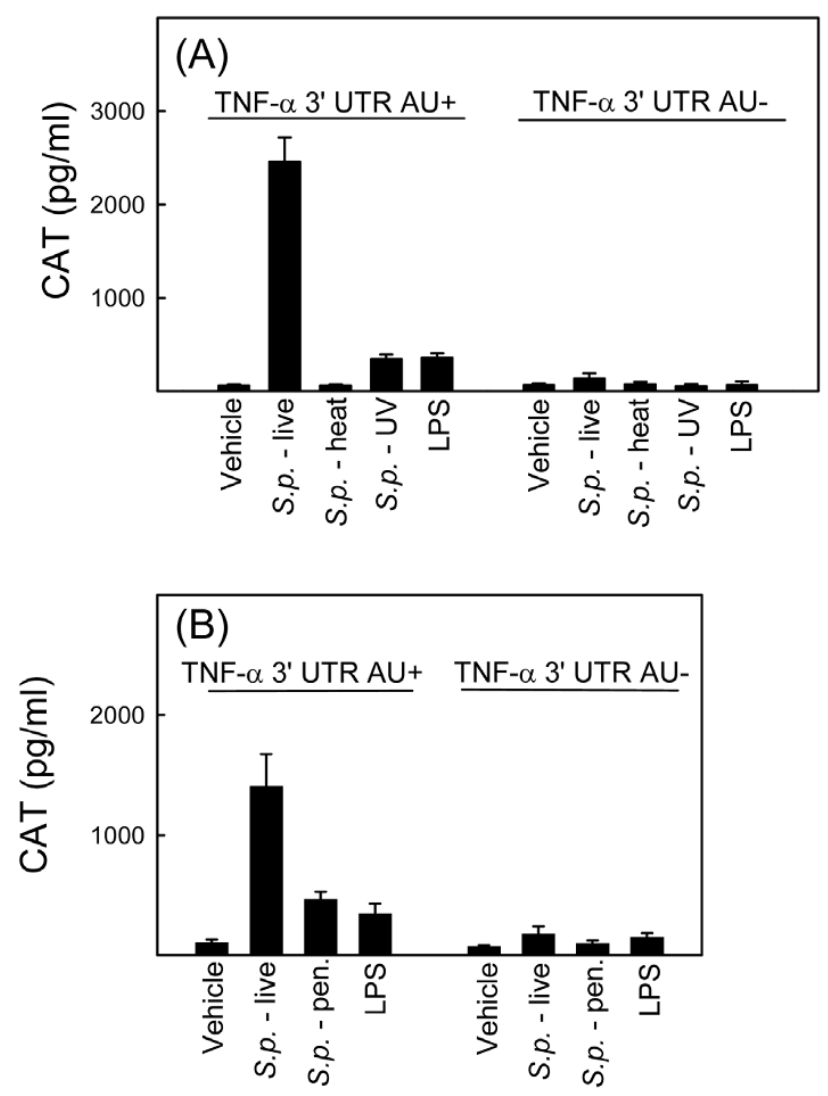

Figure 2

Stabilization of TNF- $\alpha$ mRNA by S. pneumoniae is dependent on the viability of the bacteria. RAW-TNF$\mathrm{AU}+$ and RAW-TNF-AU $\div$ cells were seeded and treated with vehicle, live pneumoniae $\left(5 \times 10^{7}\right.$ bacteria/ml), or LPS $(100 \mathrm{ng} / \mathrm{ml})$ as well as bacteria $\left(5 \times 10^{7}\right.$ bacteria/ml) killed by either (A), heat, UV, or (B) penicillin treatment. Total cell lysates were harvested $20 \mathrm{~h}$ later and CAT was measured by ELISA. The data is shown as means +/- SEM. Similar results were obtained in 2-3 independent experiments.

of TNF- $\alpha$ mRNA. We first examined how pure TLR agonists affected CAT expression in the RAW-TNF- $\alpha$ 3'-UTR $\mathrm{AU}+$ cell line and compared this with the response evoked by live S. pneumoniae. The agonists for TLR2, 4, and 9 all enhanced CAT expression but to a rather moderate extent compared to what was observed in cells receiving live $S$. pneumoniae (Fig. 3A). To directly assess the role of TLR9, we treated cells with the TLR9 antagonist ODN2088 prior to addition of $S$. pneumoniae and measured CAT expression in lysates at later time points. Although ODN2088 inhibited induction of TNF- $\alpha$ by the TLR9 agonist ODN1826 by more than $95 \%$ (data not shown), the presence of the TLR9 antagonist had no effect on CAT expression induced by $S$. pneumoniae (Fig. 3B), thus suggesting that mRNA stabilization by $S$. pneumoniae is independent of TLR9.
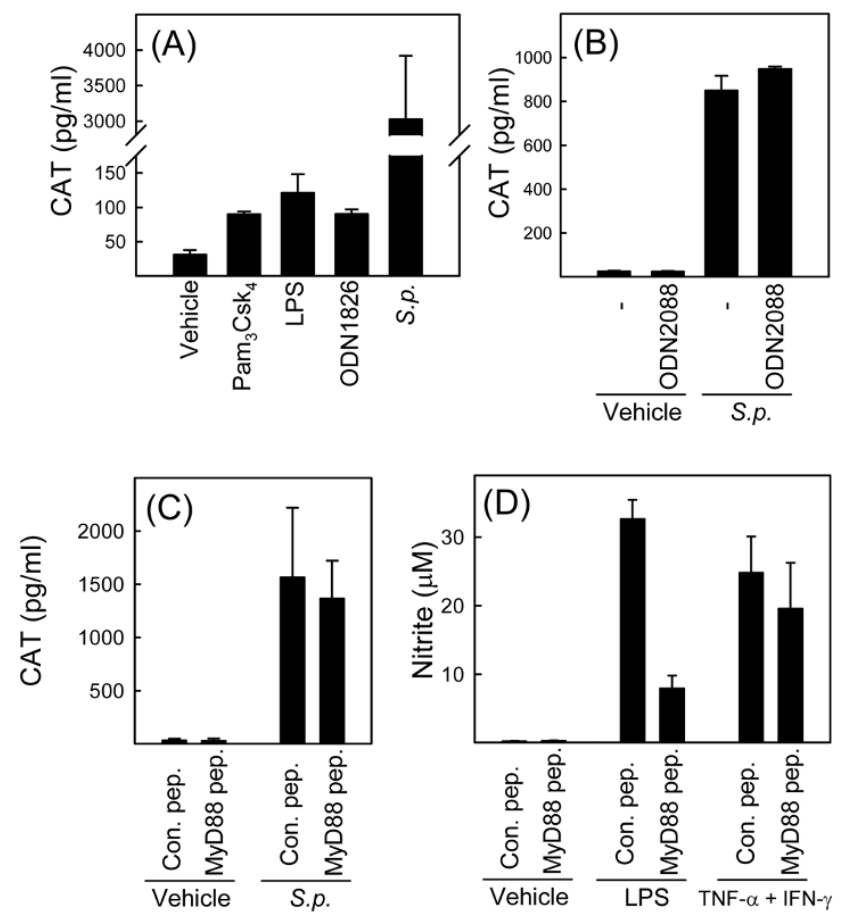

Figure 3

S. pneumoniae mediates TNF- $\alpha$ mRNA stability independent of TLRs. (A) RAW-TNF-AU+ cells were treated with vehicle, S. pneumoniae $\left(5 \times 10^{7}\right.$ bacteria/ml), LPS (I00 ng/ $\mathrm{ml})$, Pam3Csk4 (200 ng/ml), or ODNI826 (I $\mu \mathrm{M})$. Total cell lysates were harvested $20 \mathrm{~h}$ later and CAT was measured by ELISA. (B) RAW-TNF-AU+ cells were treated with the TLR9 antagonist ODN2088 (3 $\mu \mathrm{M}) 15$ min prior to addition of vehicle or $\mathrm{S}$. pneumoniae $\left(5 \times 10^{7}\right.$ bacteria $\left./ \mathrm{ml}\right)$ to the cell cultures. Total cell lysates were harvested $20 \mathrm{~h}$ later and CAT was measured by ELISA. (C and D) RAW-TNF-AU+ cells were treated with a MyD88 inhibitor peptide or a control peptide for $24 \mathrm{~h}$ before addition of $(C)$ vehicle or S. pneumoniae $\left(5 \times 10^{7}\right.$ bacteria/ml) or (D) LPS $(100 \mathrm{ng} / \mathrm{ml})$ or TNF- $\alpha$ $(25 \mathrm{ng} / \mathrm{ml})$ plus IFN- $\gamma(10 \mathrm{ng} / \mathrm{ml})$. (C) Total cell lysates were harvested $20 \mathrm{~h}$ later and CAT was measured by ELISA. (D) Supernatants were harvested $36 \mathrm{~h}$ post stimulation, and nitrite was measured by Griess assay. Similar results were obtained in 2-3 independent experiments. The data are shown as means $+/-$ SEM.

To more broadly examine the role of TLRs in stabilization of TNF- $\alpha$ mRNA during $S$. pneumoniae infection, we pretreated cells with a cell-permeable MyD88 inhibitory peptide or an inactive control peptide prior to addition of bacteria. However, this treatment did not affect $S$. pneumoniae-induced CAT expression (Fig. 3C), although the inhibitory peptide did indeed inhibit TLR signaling both strongly and specifically (Fig. 3D). Thus, the ability of $S$. pneumoniae to stabilize TNF- $\alpha$ mRNA seems to be independent of bacterial signaling through TLRs. 
P38 MAPK is important for stabilization of TNF- $\alpha$ mRNA by $\mathbf{S}$. pneumoniae

The signaling pathways responsible for mediating mRNA stability have recently been studied extensively, and it appears that P38 MAPK plays a central role in this process [13]. To examine the role of p38 in stabilization of TNF- $\alpha$ mRNA in response to $S$. pneumoniae infection, we treated the RAW TNF- $\alpha$ 3'-UTR AU+ cell line with the p38 inhibitor SB202190 15 min prior to addition of S. pneumoniae. CAT was subsequently measured in cell lysates. As shown in Fig. 4A, the strong elevation of CAT protein levels observed after infection with live S. pneumoniae was significantly inhibited by the presence of SB202190. It has been reported that the p38 MAPK inhibitor SB203580, which is structurally very similar to SB202190, not only inhibits p38 but also the kinase receptor-interacting protein (RIP) 2 [27], which plays an important role in signaling downstream of the S. pneumoniae-activated PRR NOD2 [27]. Therefore, we also examined the effect of another RIP2 inhibitor, PP2 [27], on induction of CAT protein in our reporter system However, as illustrated in Fig. 4A, no effect of PP2 treatment towards bacteria-induced CAT production was observed.

In Fig. 2 we demonstrated that live but not heat-killed $S$. pneumoniae mediated stabilization of TNF- $\alpha$ mRNA. Therefore, we hypothesized that live versus heat-killed $S$. pneumoniae may differentially activate p38. RAW264.7 cells were stimulated with live or heat-killed $S$. pneumoniae for the indicated time intervals, whole-cell lysates were harvested and the levels of phosphorylated p38 were measured. Indeed, the results showed that live bacteria potently stimulated phosphorylation of p38, heat-killed bacteria were not able to elicit such a response (Fig. 4B).

To more thoroughly study the role of p38 in S. pneumoniae-mediated mRNA stabilization, we wanted to examine how inactivation of TLR signaling, which did not affect TNF- $\alpha$ mRNA stabilization (Fig. 3), might influence p38 activation. Therefore, we pretreated RAW264.7 cells and primary macrophages with the MyD88 inhibitory peptide or an inactive control peptide prior to addition of $S$. pneumoniae. The cells were lysed $30 \mathrm{~min}$ post-infection and levels of phospho-p38 were measured. In both cell types we observed strong activation of p38 in response to $S$. pneumoniae treatment and this was independent of the presence of the MyD88 inhibitory peptide (Fig. 4C and 4D). Thus, stabilization of TNF- $\alpha$ mRNA by $S$. pneumoniae is dependent on $\mathrm{p} 38$, and this kinase is activated by live bacteria through a mechanism independent of TLRs.
P38 mediates mRNA stabilization in response to S. pneumoniae independently of the MAPK-activated protein kinases MK2, MSKI/2, and MNK

P38-mediated mRNA stabilization can occur through several mechanisms, including involvement of members of the MAPK-activated protein kinase family, in particular MK2 [28-30]. To examine the role of this family of kinases in stabilization of TNF- $\alpha$ mRNA, we compared macrophages from C57BL/6 versus MK2-/- or MSK1/2-/- mice with respect to stabilization of endogenous TNF- $\alpha$ mRNA after challenge with $S$. pneumoniae. Furthermore, we also examined the effect of the Mnk inhibitor CGP57380 on production of CAT protein in the reporter cell line system. In all cases, no role for the MAPK-activated protein kinases was found (data not shown).

\section{Activation of $\mathrm{p} 38 \mathrm{MAPK}$ in response to $\mathrm{S}$. pneumoniae is dependent on TAKI and involves MKK3}

In order to gain more insight into the mechanism of p38 activation during infection with $S$. pneumoniae, we first examined the role of TAK1, which has been ascribed an important role in this process by activating a number of different pathways [31-33]. RAW264.7 cells were seeded and treated with the TAK1 inhibitor (5Z)-7-oxozeaenol 15 min prior to stimulation with $S$. pneumoniae or anisomycin. Lysates were prepared 30 min post-stimulation, and levels of phospho-p38 were measured. As shown in Fig. 5A, both $S$. pneumoniae and anisomycin potently induced phosphorylation of $\mathrm{p} 38$. Whereas the TAK1 inhibitor did not affect activation of p38 in response to anisomycin, the ability of $S$. pneumoniae to induce p38 phosphorylation was abolished in the presence of the TAK1 inhibitor.

MKK3, as well as MKK4, and 6 are p38 upstream kinases and can be activated through TAK1 [34]. To evaluate the role of MKK3 in the $S$. pneumoniae-induced p38 activation pathway, we compared the ability of spleen cells from $\mathrm{C} 57 \mathrm{BL} / 6$ and MKK3-/- mice to activate p38 in response to $S$. pneumoniae treatment. Anisomycin was included as a control, and was found to trigger p38 activation independently of MKK3 (Fig. 5B). By contrast, MKK3-/- cells responded to $S$. pneumoniae with significantly reduced, although not abolished, activation of p38. Taken together, these data demonstrate that $S$. pneumoniae activates p38 through a TLR-independent pathway involving the upstream kinases TAK1 and MKK3.

\section{Discussion}

In this work we demonstrate that $S$. pneumoniae mediates stabilization of TNF- $\alpha$ mRNA in macrophages by a mechanism dependent on the AREs in the 3'-UTR of TNF- $\alpha$ mRNA. The pathway stimulating this mechanism is independent of TLR signaling and involves TAK1, MKK3, and p38 MAPK. 

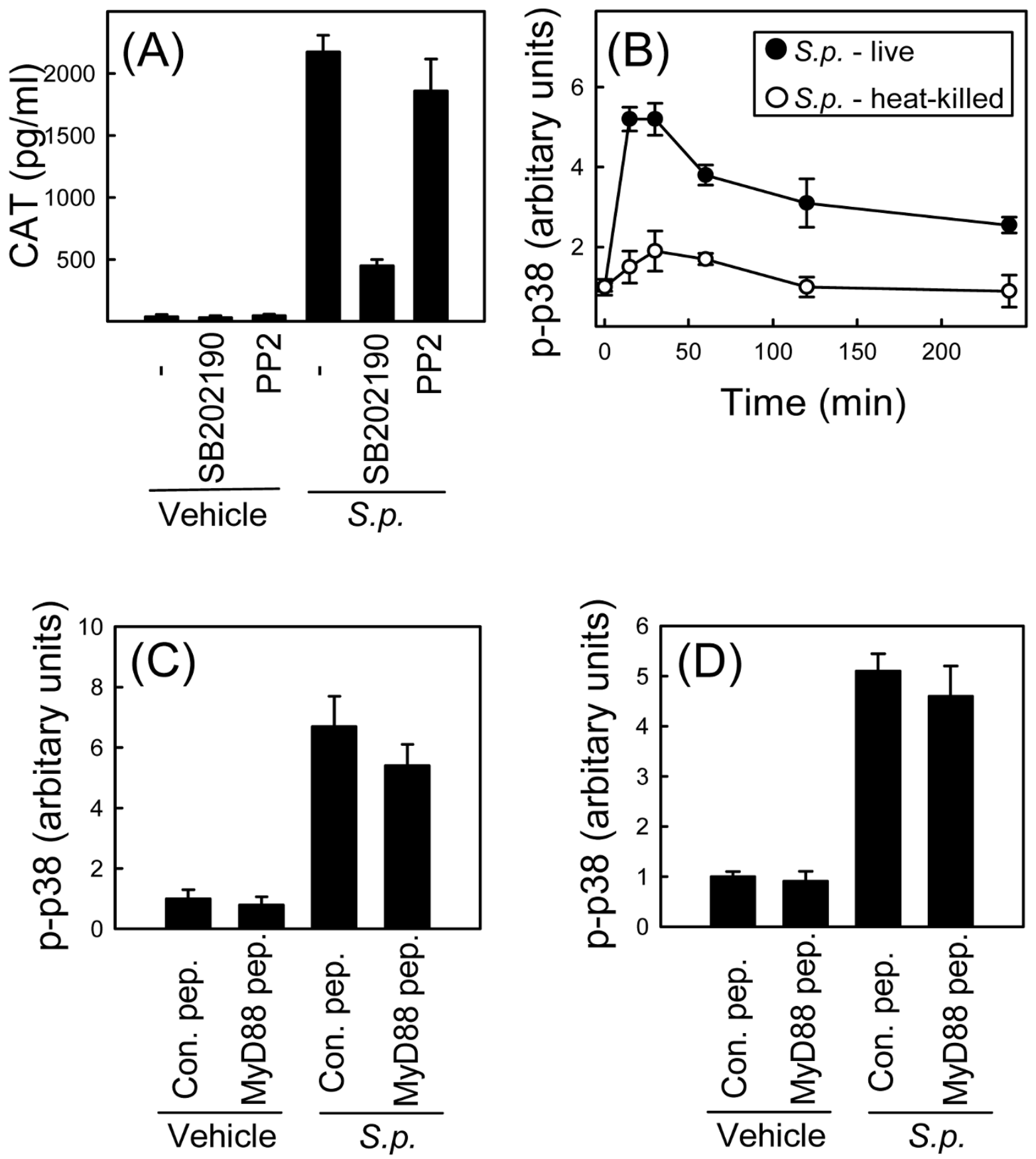

\section{Figure 4}

P38 MAPK is important for stabilization of TNF- $\alpha$ mRNA by S. pneumoniae. (A) RAW-TNF-AU+ cells were treated with the inhibitors SB202190 (p38 and RIP2) $(5 \mu \mathrm{M})$ and PP2 (Src and RIP2) (500 nM) 15 min prior to addition of vehicle or S. pneumoniae $\left(5 \times 10^{7}\right.$ bacteria/ml $)$ to the cell cultures. Total cell lysates were harvested $20 \mathrm{~h}$ later and CAT was measured by ELISA. The data is shown as means +/- SEM. (B) RAW264.7 cells were treated with live or heat-killed S. pneumoniae $\left(5 \times 10^{7}\right.$ bacteria/ml) for the indicated amount of time, and whole cell lysates were isolated. Phosphorylation of $\mathrm{p} 38$ was measured by Luminex. The data is shown as means +/- SEM. (C and D) RAW264.7 (C) and C57BL/6 macrophages (D) were incubated with a MyD88 inhibitor peptide or a control peptide for $24 \mathrm{~h}$ before addition of vehicle or $\mathrm{S}$. pneumoniae $\left(5 \times 10^{7} \mathrm{bacteria} / \mathrm{ml}\right)$. Whole cell lysates were harvested 30 min later and phosphorylation of p38 was measured by Luminex. The data is shown as means +/- SEM. Similar results were obtained in 2-3 independent experiments. 

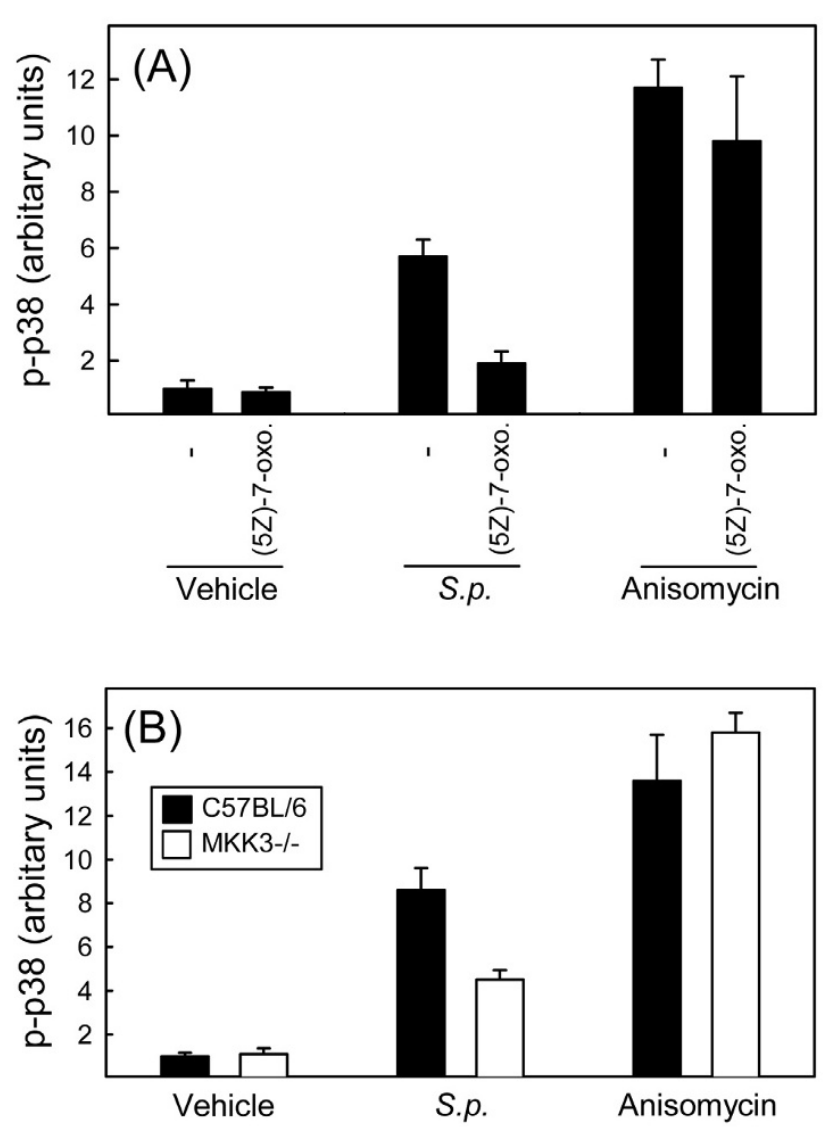

Figure 5

Activation of p38 MAPK in response to $S$. pneumoniae is dependent on TAKI and involves MKK3. (A)

RAW264.7 cells were seeded in triplicate cultures and left overnight to settle. Fifteen min prior to stimulation, some wells received I $\mu$ M of (5Z)-7-oxozeaenol. The cells were stimulated with $S$. pneumoniae $\left(5 \times 10^{7}\right.$ bacteria/ml) or anisomycin $(100 \mathrm{ng} / \mathrm{ml})$ for $30 \mathrm{~min}$, and whole-cell lysates were prepared. (B) Spleen cells from C57BL/6 and MKK3-/- mice were seeded in triplicates and left overnight to settle. The cells were stimulated with $S$. pneumoniae $\left(5 \times 10^{7}\right.$ bacteria/ $\mathrm{ml})$ or anisomycin $(100 \mathrm{ng} / \mathrm{ml})$ for $30 \mathrm{~min}$, and whole-cell lysates were prepared. Phosphorylation of p38 MAPK was measured by Luminex, and data is presented as means +/SEM. Similar results were obtained in 2 independent experiments.

An important finding of this work is that recognition systems independent of TLRs are responsible for triggering $S$. pneumoniae-induced signal transduction leading to stabilization of TNF- $\alpha$ mRNA. Here we did not identify an alternative PRR responsible for activating the p38-dependent signal. It has been reported that $S$. pneumoniae is recognized by NOD2, which does indeed signal to p38 [24]. However, since inactivated $S$. pneumoniae should retain the capacity to activate NOD2, and we found that the
RIP2 inhibitor PP2 did not affect expression of the CAT reporter, our data suggest that the observed stabilization of TNF- $\alpha$ mRNA by live $S$. pneumoniae does not depend on NOD2. In addition, there is evidence that other receptor systems may be involved in shaping the inflammatory cytokine response during bacterial infections. For instance, it has been reported that Borrelia burgdorferi can induce intracellular signaling and inflammatory gene expression independent of TLRs through direct binding to integrin $\alpha 3$ and $\beta 1$ [35].

The present finding of only live $S$. pneumoniae being able to induce TNF- $\alpha$ mRNA stability suggests that a product or activity of the bacterial life cycle is required to trigger the p38-dependent signal mediating mRNA stability. Similar findings have been previously reported for other bacteria, since Kumar et al. demonstrated that live as opposed to heat-killed Staphylococcus aureus were able to stimulate phosphorylation of the MAPKs p38 and JNK, as well as the NF- $\kappa$ B inhibitory protein I $\mathrm{B}[36]$. In that study, however, the effects of live bacteria may have been attributable to bacterial exoproducts, since the conditioned medium of $S$. aureus also stimulated the signalling pathways [36].

The ability of $S$. pneumoniae to induce mRNA stabilization was abrogated in the presence of the p38 MAPK inhibitor SB202190, suggesting a role for this kinase. In addition, the signaling pathway to p38 was entirely dependent on TAK1 and partially dependent on MKK3. P38 MAPK is a well-described mediator of mRNA stabilization affecting the activity of a number of ARE-binding proteins [13,37]. For instance, p38 activates the kinase MK2, which phosphorylates tristetraprolin (TTP), an ARE-binding protein with mRNA-destabilizing activity [28]. This phosphorylation event decreases the ARE affinity of TTP, hence leading to increased mRNA stability. Another mechanism involves HuR, which is induced by P38 MAPK and binds to the AREs, thus stabilizing TNF- $\alpha$ mRNA $[29,30]$. In this work we did not systematically investigate the molecular mechanism of mRNA stabilization in response to $S$. pneumoniae infection, although we did find that it was independent of the MAPK-activated protein kinases MK2, MSK1/2, and MNK.

\section{Conclusion}

Here we report that live $S$. pneumoniae stabilizes TNF- $\alpha$ mRNA and that this is dependent on the AREs in the 3'UTR of the mRNA. The bacteria-induced signals mediating this function were not transduced from TLRs but were dependent on the p38 MAPK, the upstream activation of which was dependent on TAK1 and MKK3. Given the important role of TNF- $\alpha$ in the inflammatory response, the present study provides new insight into the mechanisms that govern production of inflammatory mediators in macrophages during pneumococcal infection. 


\section{Methods \\ Mice and cells}

C57BL/6, MK2-/-, MSK1/2-/-, MKK3-/- mice were obtained from Taconic (Laven, Denmark), professor Mathias Gaestel (Hannover, Germany), professor Simon Arthur (Dundee, UK), and professor Richard A Flavell (Yale, USA), respectively, and bred in the animal facility of The Faculty of Health Sciences, University of Aarhus, under pathogen-free conditions. Peritoneal macrophages were harvested by lavage of the peritoneal cavity with PBS supplemented with 5\% LPS-free heat-inactivated fetal calf serum (FCS) (Cambrex, Baltimore, MD, USA) and $400 \mu \mathrm{l}$ heparin (Leo Pharma, Copenhagen, Denmark) per 100 ml. RAW264.7 macrophage-like cells and the derived cell lines RAW TNF- $\alpha$ 3' untranslated region (UTR) AU+ and RAW TNF- $\alpha$ 3'UTR AU $\div$ [38-40] were maintained in DMEM supplemented with 5\% FCS, antibiotics and for the latter 2 cell lines also with $500 \mu \mathrm{g} / \mathrm{ml}$ G418 (Roche, Basel, Switzerland). For experiments, primary macrophages were seeded in 96-well or 6-well tissue plates in RPMI 1640 medium containing $5 \%$ FCS at a density of 3.0 $\times 10^{5}$ and $6.0 \times 10^{6}$ cells per well, respectively. RAW264.7 and derived cell lines were seeded in 96-well or 6-well tissue plates at a density of $1.0 \times 10^{5}$ and $6.0 \times 10^{6}$ cells per well, respectively. After seeding, cells were left overnight to settle before further treatment.

\section{Bacteria}

The bacteria used were the $S$. pneumoniae strain SK1013 serotype 4 (TIGR4) and the N. meningitidis strain NGO93 serogroup B, serotype 15:P1.2, MLEE cluster I1, ET76. The bacteria were grown overnight in Brain Heart Infusion broth with $10 \%$ Levinthal broth (Statens Serum Institute, Copenhagen) reaching a concentration of $18.0 \pm 2.2 \times 10^{8}$ bacteria per $\mathrm{ml}$ as determined in a Thoma counting chamber. For stimulation, $300 \mu \mathrm{l}$ and $10 \mu \mathrm{l}$ from this stock was added to the cell cultures in 6- and 96-well plates, respectively, reaching final volumes of $3 \mathrm{ml}$ and $100 \mu \mathrm{l}$, respectively. The bacteria were heat-inactivated by incubation of the cultures for $30 \mathrm{~min}$ at $65^{\circ} \mathrm{C}$. To UV-inactivate the bacteria, the cultures were exposed to UV light for $10 \mathrm{~min}$, and for killing of bacteria with penicillin, the cultures were incubated for $2 \mathrm{~h}$ with $1.0 \mu \mathrm{g} / \mathrm{ml}$ of the antibiotics.

\section{Reagents}

The TLR agonists Pam3Csk4, LPS, and ODN1826 as well as the TLR9 antagonist ODN2088 were obtained from InvivoGen (San Diego, CA, USA). The MyD88 Homodimerization Inhibitory Peptide was purchased from IMGENEX (San Diego, CA, USA). Actinomycin D, anisomycin, SB202190, and PP2 were from Calbiochem (San Diego, CA, USA). The TAK1 inhibitor (5Z)-7-oxozeaenol was purchased from AnalytiCon Discovery $\mathrm{GmbH}$. The cytokines TNF- $\alpha$, and interferon (IFN)- $\gamma$ were from R\&D Systems (Minneapolis, MN, USA). The Mnk inhibi- tor CGP57380 was kindly provided by Hermann Gram (Novatis).

\section{TNF- $\alpha$ ELISA}

For measurement of TNF- $\alpha$. an ELISA duoset from R\&D Systems was used, following recommendations of the manufacturer. The concentrations of coating $\mathrm{Ab}$ and detection $\mathrm{Ab}$ were 0.8 and $0.15 \mathrm{mg} / \mathrm{ml}$, respectively. The ELISA was able to detect TNF- $\alpha$ from 15 to $2000 \mathrm{pg} / \mathrm{ml}$.

\section{Purification of RNA and Real-time PCR}

Total RNA was extracted with TRIzol (Invitrogen, Carlsbad, CA, USA) according to the recommendations of the manufacturer. Briefly, cells were lysed in TRIzol, and chloroform was added, followed by phase separation by centrifugation. RNA was precipitated with isopropanol and pelleted by centrifugation. Pellets were washed with $80 \%$ ethanol and re-dissolved in RNase-free water. For cDNA generation, $1 \mu \mathrm{g}$ of RNA was subjected to reverse transcription (RT) with oligo(dT) as primer and Expand Reverse Transcriptase (both from Roche). Prior to RTPCR, RNA was treated with DNase I (Ambion, Austin, TX, USA) to remove any contaminating DNA, the absence of which was confirmed in control experiments where the reverse transcriptase enzyme was omitted (data not shown). To measure the relative amount of TNF- $\alpha$ mRNAs, amplification of sample cDNA was monitored with the fluorescent DNA binding dye SYBR (QIAGEN). The PCR primers used in this study were: TNF-forward, TGGGAGTAGACAAGGTACAACCC; TNF-reverse, AGAGGGAAATCGTGCGTGAC; $\beta$-actin-forward, GCTCCCCGGGCTGTATTCC; $\beta$-actin-reverse, CTCTCTTGCTCTGGG CCTCGT). The data on TNF- $\alpha$ were normalized to $\beta$-actin, and presented as normalized ratio.

\section{Measurement of CAT levels}

The cells were seeded and treated as described for the appropriate amount of time. For cell lysis and measurement of CAT levels the CAT ELISA kit from Roche (Basel, Switzerland) was used.

\section{Preparation of whole cell extracts}

To assay for levels of total and phosphorylated p38, cells were seeded in 6-well plates as described above and stimulated with bacteria as specified in the text. At different time points post-stimulation, cells were lysed using the Bio-Plex Cell Lysis Kit (Bio-Rad, Hercules, CA, USA) according to the recommendations of the manufacturer. Briefly, the cells were washed with $3 \mathrm{ml}$ Cell Wash Buffer per well and treated with $1 \mathrm{ml}$ Lysing Solution supplemented with PMSF followed by incubation for $20 \mathrm{~min}$ at $4^{\circ} \mathrm{C}$. The suspension was centrifuged at $4500 \times \mathrm{g}$ for 20 $\min$ at $4^{\circ} \mathrm{C}$ and supernatants were harvested as whole-cell extracts. 


\section{Luminex}

The levels of total and phosphorylated p38 were measured using the Luminex Technology ${ }^{\mathrm{TM}}$ and kits purchased from Bio-Rad. Briefly, the filter plate was washed with assay buffer and freshly vortexed antibody-conjugated beads were added to each well. The plate was washed with assay buffer and samples (45 $\mu \mathrm{g}$ of protein in $50 \mu \mathrm{l}$ lysis buffer) were added. After a brief shake (30 sec at 1.100 $\mathrm{rpm})$, the plate was incubated with shaking (300 rpm) overnight at $4^{\circ} \mathrm{C}$. After a wash-step, detection antibody was added to each well, and the plate was shaken and incubated shaking $(300 \mathrm{rpm})$ at room-temperature in the dark for $45 \mathrm{~min}$ to $2 \mathrm{~h}$. Subsequently, the plate was washed and incubated for $10 \mathrm{~min}$ with $50 \mu \mathrm{l}$ of a streptavidine-PE solution with shaking (30 sec at $1.100 \mathrm{rpm}, 10$ min $300 \mathrm{rpm}$ ). Finally the plate was washed and $125 \mu \mathrm{l}$ of assay buffer was added to each well and the plate was shaken for $10 \mathrm{sec}$ at $1100 \mathrm{rpm}$ and read immediately on the Bio-Plex reader.

\section{Nitrite determination}

Nitrite is generated by the rapid oxidation of NO. It is stable and its accumulation in the culture medium reflects the amount of NO produced. To assay nitrite we used the Griess reaction. Aliquots of $100 \mu$ l culture supernatants were mixed with equal volumes of Griess reagent (equal volumes of $0.1 \% \mathrm{~N}$-(1-naphthyl)-ethylenediamine dihydrochloride and 1\% p-aminobenzene sulphanilamide diluted in $2.5 \%$ phosphoric acid) in a 96-well microtitre plate (Maxisorb Immunoplate, Nunc). After 10 min incubation at room temperature the absorbance at a wavelength of $540 \mathrm{~nm}$ was measured in a microplate reader (model 450; Bio-Rad). A range of 2-fold dilutions of sodium nitrite ( 0.05 to $100 \mu \mathrm{M})$ in RPMI medium was run in each assay to generate a standard curve. In most experiments, control cultures not infected or stimulated gave small nitrite values in the order of $0-1 \mu \mathrm{M}$. These figures were subtracted from the experimental values in the data presentation.

\section{Ethics}

The work presented in this paper did not include research on humans. Animals, used for isolation of cells for in vitro experiments were sacrificed by cervical dislocation without receiving any prior experimental treatment. Therefore, to perform the experiments described in this article, no need for approval from ethics committees was required according to Danish law.

\section{Abbreviations}

ARE: adenylate uridylate rich elements; AU: adenylate uridylate; CAT: chloramphenicol acetyl transferase; FCS: fetal calf serum; MAPK: mitogen-activated protein kinase; MKK: mitogen-activated protein kinase kinase; NF: nuclear factor; NOD: nucleotide-binding oligomerization domain; PAMP: pathogen-associated molecular pattern; PRR: pattern recognition receptor; RIP: receptor-interacting protein; TAK: transforming growth factor-activated kinase; TLR: Toll-like receptor; TNF: tumor necrosis factor; UTR: untranslated region.

\section{Competing interests}

The authors declare that they have no competing interests.

\section{Authors' contributions}

THM and SRP designed experiments. THM and RSB performed experiments. THM, RSB, and SRP interpreted data. All authors helped preparing the manuscript and approved the final version.

\section{Acknowledgements}

The authors wish to thank Tove Findahl and Kirsten Stadel Pedersen for excellent technical assistance. This work was supported by grants from Beckett fonden, Helga og Peter Kornings Fond, Gangstedfonden, and The Danish Medical Research Council (grant no: 27I-06-0438).

\section{References}

I. Koedel U, Scheld WM, Pfister HW: Pathogenesis and pathophysiology of pneumococcal meningitis. Lancet Infect Dis 2002, 2:721-736.

2. Obaro S, Adegbola R: The pneumococcus: carriage, disease and conjugate vaccines. J Med Microbiol 2002, 5 I:98-104.

3. Albiger B, Dahlberg S, Sandgren A, Wartha F, Beiter K, Katsuragi H, et al: Toll-like receptor 9 acts at an early stage in host defence against pneumococcal infection. Cell Microbiol 2007, 9:633-644.

4. Parsons HK, Dockrell DH: The burden of invasive pneumococcal disease and the potential for reduction by immunisation. Int J Antimicrob Agents 2002, 19:85-93.

5. Moore LJ, Pridmore AC, Lee ME, Read RC: Induction of proinflammatory cytokine release by human macrophages during exposure of Streptococcus pneumoniae to penicillin is influenced by minimum inhibitory concentration ratio. Int J Antimicrob Agents 2005, 26:188-196.

6. Clark IA: How TNF was recognized as a key mechanism of disease. Cytokine Growth Factor Rev 2007, 18:335-343.

7. Keane J, Gershon S, Wise RP, Mirabile-Levens E, Kasznica J, Schwieterman WD, et al:: Tuberculosis associated with infliximab, a tumor necrosis factor alpha-neutralizing agent. N EnglJ Med 200I, 345:1098-II04.

8. Rothe J, Lesslauer W, Lotscher H, Lang Y, Koebel P, Kontgen F, et al:: Mice lacking the tumour necrosis factor receptor I are resistant to TNF-mediated toxicity but highly susceptible to infection by Listeria monocytogenes. Nature 1993, 364:798-802.

9. Kirby AC, Raynes JG, Kaye PM: The role played by tumor necrosis factor during localized and systemic infection with Streptococcus pneumoniae. J Infect Dis 2005, 191:1538-1547.

10. Tsao N, Chang WW, Liu CC, Lei HY: Development of hematogenous pneumococcal meningitis in adult mice: the role of TNF-alpha. FEMS Immunol Med Microbiol 2002, 32: I33-I40.

II. Piecyk M, Wax S, Beck AR, Kedersha N, Gupta M, Maritim B, et al.: TIA-I is a translational silencer that selectively regulates the expression of TNF-alpha. EMBO J 2000, 19:4I54-4163.

12. Kontoyiannis D, Pasparakis M, Pizarro TT, Cominelli F, Kollias G: Impaired on/off regulation of TNF biosynthesis in mice lacking TNF AU-rich elements: implications for joint and gutassociated immunopathologies. Immunity 1999, 10:387-398.

13. Anderson P, Phillips K, Stoecklin G, Kedersha N: Post-transcriptional regulation of proinflammatory proteins. I Leukoc Biol 2004, 76:42-47.

14. Zhang T, Kruys V, Huez G, Gueydan C: AU-rich element-mediated translational control: complexity and multiple activities of trans-activating factors. Biochem Soc Trans 2002, 30:952-958. 
15. Akira S, Uematsu S, Takeuchi O: Pathogen recognition and innate immunity. Cell 2006, I24:783-80I.

16. Mogensen TH, Paludan SR, Kilian M, Ostergaard L: Live Streptococcus pneumoniae, Haemophilus influenzae, and Neisseria meningitidis activate the inflammatory response through Toll-like receptors 2,4 , and 9 in species-specific patterns. J Leukoc Biol 2006, 80:267-277.

17. Moore LJ, Pridmore AC, Dower SK, Read RC: Penicillin enhances the toll-like receptor 2-mediated proinflammatory activity of Streptococcus pneumoniae. J Infect Dis 2003, I 88: 1040- 1048

18. Yoshimura A, Lien E, Ingalls RR, Tuomanen E, Dziarski R, Golenbock $D$ : Cutting edge: recognition of Gram-positive bacterial cell wall components by the innate immune system occurs via Toll-like receptor 2. J Immunol 1999, 163:I-5.

19. Malley R, Henneke P, Morse SC, Cieslewicz MJ, Lipsitch M, Thompson CM, et al.: Recognition of pneumolysin by Toll-like receptor 4 confers resistance to pneumococcal infection. Proc Natl Acad Sci USA 2003, 100:1966-197|.

20. Branger J, Knapp S, Weijer S, Leemans JC, Pater JM, Speelman P, et al: Role of Toll-like receptor $\mathbf{4}$ in gram-positive and gram-negative pneumonia in mice. Infect Immun 2004, 72:788-794.

21. Akira S, Takeda K: Toll-like receptor signalling. Nat Rev Immunol 2004, 4:499-5II.

22. Koedel U, Rupprecht T, Angele B, Heesemann J, Wagner H, Pfister HW, et al: MyD88 is required for mounting a robust host immune response to Streptococcus pneumoniae in the CNS. Brain 2004, I 27: | 437-| 1445 .

23. Wellmer A, Zysk G, Gerber J, Kunst T, Von Mering M, Bunkowski S, et al:: Decreased virulence of a pneumolysin-deficient strain of Streptococcus pneumoniae in murine meningitis. Infect Immun 2002, 70:6504-6508.

24. Inohara N, Chamaillard, McDonald C, Nunez G: NOD-LRR proteins: role in host-microbial interactions and inflammatory disease. Annu Rev Biochem 2005, 74:355-383.

25. Opitz B, Puschel A, Schmeck B, Hocke AC, Rosseau S, Hammerschmidt $S$, et al.: Nucleotide-binding oligomerization domain proteins are innate immune receptors for internalized Streptococcus pneumoniae. J Biol Chem 2004, 279:36426-36432.

26. Hemmi H, Takeuchi O, Kawai T, Kaisho T, Sato S, Sanjo H, et al.: A Toll-like receptor recognizes bacterial DNA. Nature 2000 408:740-745.

27. Windheim M, Lang C, Peggie M, Plater LA, Cohen P: Molecular mechanisms involved in the regulation of cytokine production by muramyl dipeptide. Biochem J 2007, 404:179-190.

28. Hitti E, lakovleva T, Brook M, Deppenmeier S, Gruber AD, Radzioch $D$, et al.: Mitogen-activated protein kinase-activated protein kinase 2 regulates tumor necrosis factor mRNA stability and translation mainly by altering tristetraprolin expression, stability, and binding to adenine/uridine-rich element. Mol Cell Biol 2006, 26:2399-2407.

29. Brennan CM, Steitz JA: HuR and mRNA stability. Cell Mol Life Sci 200I, 58:266-277.

30. Rajasingh J, Bord E, Luedemann C, Asai J, Hamada $\mathrm{H}$, Thorne $\mathrm{T}$, et al: IL-I 0 -induced TNF-alpha mRNA destabilization is mediated via IL- 10 suppression of $\mathrm{p} 38$ MAP kinase activation and inhibition of HuR expression. FASEB | 2006, 20:2 I I2-2 II4.

31. Sato S, Sanjo H, Takeda K, Ninomiya-Tsuji J, Yamamoto M, Kawai T, et al.: Essential function for the kinase TAKI in innate and adaptive immune responses. Nat Immunol 2005, 6:1087-1095.

32. Shim JH, Xiao C, Paschal AE, Bailey ST, Rao P, Hayden MS, et al.: TAK1, but not TAB I or TAB2, plays an essential role in multiple signaling pathways in vivo. Genes Dev 2005, 19:2668-268I.

33. Kumar A, Takada Y, Boriek AM, Aggarwal BB: Nuclear factor-kappaB: its role in health and disease. Mol Med 2004, 82:434-448.

34. Wang C, Deng L, Hong M, Akkaraju GR, Inoue J, Chen ZJ: TAKI is a ubiquitin-dependent kinase of MKK and IKK. Nature 200I, 412:346-35I.

35. Behera AK, Hildebrand E, Uematsu S, Akira S, Coburn J, Hu LT: Identification of a TLR-independent pathway for Borrelia burgdorferi-induced expression of matrix metalloproteinases and inflammatory mediators through binding to integrin alpha 3 beta I. J Immunol 2006, 177:657-664.

36. Kumar A, Zhang J, Yu FS: Innate immune response of corneal epithelial cells to Staphylococcus aureus infection: role of peptidoglycan in stimulating proinflammatory cytokine secretion. Invest Ophthalmol Vis Sci 2004, 45:35I3-3522.
37. Dean JL, Sully G, Clark AR, Saklatvala J: The involvement of AUrich element-binding proteins in $\mathrm{p} 38$ mitogen-activated protein kinase pathway-mediated mRNA stabilisation. Cell Signal 2004, 16: II|3-II2I.

38. Han J, Brown T, Beutler B: Endotoxin-responsive sequences control cachectin/tumor necrosis factor biosynthesis at the translational level. J Exp Med 1990, I 7 I:465-475.

39. Willeaume V, Kruys V, Mijatovic T, Huez G: Tumor necrosis factor-alpha production induced by viruses and by lipopolysaccharides in macrophages: similarities and differences. J Inflamm 1995, 46: I- I2.

40. Paludan SR, Ellermann-Eriksen S, Kruys V, Mogensen SC: Expression of TNF-alpha by herpes simplex virus-infected macrophages is regulated by a dual mechanism: transcriptional regulation by NF-kappa B and activating transcription factor $2 /$ Jun and translational regulation through the AU-rich region of the $3^{\prime \prime}$ untranslated region. J Immunol 200I, 167:2202-2208.

Publish with Bio Med Central and every scientist can read your work free of charge

"BioMed Central will be the most significant development for disseminating the results of biomedical research in our lifetime. "

Sir Paul Nurse, Cancer Research UK

Your research papers will be:

- available free of charge to the entire biomedical community

- peer reviewed and published immediately upon acceptance

- cited in PubMed and archived on PubMed Central

- yours - you keep the copyright
BiolMedcentral 